\title{
EDUCATIONAL VALUES IN AL-HADID'S SURAH AND ITS RELEVANCE TO CONTEMPORARY EDUCATION
}

\section{NILAI-NILAI PENDIDIKAN DALAM SURAH AL-HADID DAN RELEVANSINYA TERHADAP PENDIDIKAN KONTEMPORER}

\author{
Lahmuddin Lubis ${ }^{1}$, Achyar Zein ${ }^{2}$, Imron Bima Saputra ${ }^{3}$, Rahmadi Ali ${ }^{4}$ \\ ${ }^{1,2,3}$ Pascasarjana Universitas Islam Negeri Sumatera Utara \\ ${ }^{4}$ Universitas Muslim Nusantara Al Washliyah Medan \\ email: lahmuddindiversita@yahoo.com \\ email: achyarzein@gmail.com \\ email:imronbima0401@gmail.com \\ email: rahmadi.ali2121@gmail.com
}

\section{Received: 28/06/2020, Accepted: 25/08/2020, Published: 29/08/2020}

\begin{abstract}
This study aims 1) To describe the values contained in the Quran surah Al-Hadi d, and 2) To scribe the relevance of the educational values contained in surah Al-Hadid to contemporary education. This study uses qualitative methods, and this research concerns the concept of education in the Quran. The approach used is the approach of education and interpretation through the verses of the Quran. This research focuses on surah Al-Hadid in the Quran. The object of this study to the Quran, the approach used is the method of interpretation with tahlili, which is supported by the maudhu'i method. The results showed that: 1. Education values contained in the Quran in the Surah Al-Hadid consisting of 29 verses are as follows: 1) Praying for charity, 2) Commands of faith in Allah, 3) Prohibition of being arrogant, 4) Uphold justice, 5) Prompts for forgiveness, 6) Prohibition of miserly behavior / stingy, 7) Prompts in the form of punishment, 8) Reward in the form of rewards, 9) Nature of life in the world, 10) Trust in qadha and qadar, 11) Glorify Allah Almighty at all times, 12) Prayers of remembrance (remember Allah S.W.T.), 13) The virtue of the grace of Allah, 14) Book as a guide, 15) Prohibition of hypocrites. 2. The overall relevance illustrates the independence of education, justice, and humility in the assembly, which contains moral messages and lessons to be implemented in daily life that are sourced from the Quran, especially in today's era which is always related to increasingly complex crimeElitist education, excellent schools/madrasas.
\end{abstract}

Keyword: values, education, surah Al-Hadid.

\section{ABSTRAK}

Penelitian ini bertujuan: 1) untuk mendeskripsikan nilai-nilai yang terkandung dalam AlQur'an surah Al-Hadid, dan 2) untuk mendeskripsikan relevansi nilai-nilai pendidikan yang terkandung pada surah Al-Hadid terhadap pendidikan kontemporer. Penelitian ini menggunakan metode kualitatif, dan membahas tentang konsep pendidikan yang terdapat dalam Al-Qur'an, maka adapun pendekatan yang diterapkan ialah pendekatan dengan ilmu tafsir yang mengkaji ayat-ayat dalam Al-Qur'an. Fokus penelitian ini tertuju pada surah alHadid. Untuk mendapatkan fokus tema maka penelitian ini memakai metode Tahlilli yang juga didukung dengan metode maudhu'i. Hasil dari penelitian menunjukkan bahwa: 1. Nilai-nilai pendidikan yang terkandung dalam Al-Qur'an pada surah Al-Hadid yang terdiri dari 29 ayat adalah sebagai berikut: 1) Anjuran bersedekah, 2) Perintah beriman kepada Allah S.W.T., 3) Larangan bersikap sombong, 4) Menegakkan keadilan, 5) Anjuran meminta 
ampun, 6) Larangan berperilaku kikir/pelit, 7) Anjuran berupa hukuman (Punishment), 8) Balasan berupa hadiah (Reward), 9) Hakikat hidup di dunia, 10) Percaya kepada qadha dan qadar, 11) Bertasbih kepada Allah S.W.T. di setiap waktu, 12) Anjuran berzikir (mengingat Allah swt), 13) Keutamaan karunia Allah S.W.T., 14) Kitab sebagai petunjuk, 15) Larangan munafik. 2. Relevansi seluruhnya menggambarkan kemandirian dalam pendidikan, keadilan dan kerendahan hati, bersikap sosial dengan baik dan kandungan dalam penelitian surah Al- Hadid ini mengandung suatu moral dan pendidikan yang bisa diterapkan dalam kehidupan yang bersumber dari Al-Qur'an, khusunya pada era ini yang jauh dari nilai-nilai Al-Qur'an sehingga maraknya kriminalitas.

Kata Kunci: nilai, pendidikan, surah Al-Hadid.

\section{A. PENDAHULUAN}

Hakikatnya, unsur etika itu sangat terkait dengan nilai. Filsafat nilai juga biasanya disebut sebagai etika, yang membahas tentang nilai-nilai moral itu sendiri sebagai landasan dari tindakan dan sikap manusia dari berbagai tinjauan kehidupan. Esensi dari etika dan moral dapat dilahirkan dari sebuah pemikiran seseorang, budaya, kebiasaan, keyakinan sampai dari ajaran prinsip agama itu sendiri. Dalam perspektif etika Pendidikan Islam, Al-Qur'an dan As-Sunnah Nabi Muhammad S.A.W. merupakan nilai-nilai yang paling benar, kemudian berkembang oleh hasil dari ijtihad para ulama dan cendikiawan. Menurut Said Agil Husin Al Munawar (2005: 3) Segala nilai-nilai yang yang dihasilkan dari adat istiadat ataupun tradisi dan keyakinan atau ideologi sangat rentan dan relatif, dan bersifat lokal, adapun nilai-nilai yang berpusat pada AlQur'an yang disebut Qurani bersifat kuat dan mutlak juga universal, sehingga melahirkan pendidikan yang berkualitas dan mandiri dapat menyukseskan tujuan pembangunan nasional sekaligus mampu mencerdaskan bangsa (Saihu, 2019: 230).

Menurut Abdul Khobir (2007: 37) nilai tidak hanya berorientasi pada kebutuhan intelektual dan kebutuhan manusia saja, melainkan nilai pada hakikatnya berperan dalam membina dan mendidik manusia agar menjadi kepribadian yang berbudi luhur, dewasa, bermartabat, sesuai dengan fitrah penciptaannya dari Sang Khalik, dan kepribadian secara utuh dibentuk melalui pengaruh lingkungan, khususnya kependidikan (Saihu, 2019: 200). Menurut Muhammad Zein (2005: 3) Teori nilai merupakan bagian penting dalam dunia pendidikan. Begitu dengan treansfor nilainilai itu sendiri, merupakan suatu jalan proses dari pengajaran dan pendididikan.

Menurut Sudirman N. (1992: 4), secara etimologi bahwa pendidikan itu sendiri dapat diartikan sebagai cara, hal dan sebagainya, sedangkan terminologinya adalah suatu usaha yang 
dilakukan oleh individu atau sekelompok dari orang lain agar tercapainya sikap dewasa dan dapat menggapai kehidupan yang lebih tinggi lagi.

Menurut Darwin Syah (2007: 4), pendidikan merupakan suatu daya dan upaya yang sadar untuk menggapai semangat belajar dan reaksi belajar mengajar agar peserta didik dapat mengeluarkan kemampuan dalam dirinya untuk mendapat kekuatan spiritual, intelektual, sosial, pengelolaan diri, budi pekerti serta terampil yang dibutuhkan oleh dirinya sendiri, keluarga, publik, umat, bangsa bahkan dunia. Saihu (2020: 100) juga mengungkapkan, bahwa pendidikan mampu menjadikan manusia unggul dari makhluk-makhluk lainnya serta dapat menjalankan fungsi kepemimpinannya di muka bumi, lebih lanjut saihu mengungkapkan, pendidikan mengarahkan seseorang pada suatu pencapaian yang tertinggi, sebagai manusia unggul (Saihu, 2019: 272).

Berdasarkan pemaparan tersebut, maka peneliti dapat meringkas bahwa sesungguhnya pendidikan itu sendiri mengarah kepada daya dan upaya individu agar mampu mengombinasikan kemampuan yang ada dalam dirinya yang sesuai dengan kodrat manusia itu sendiri, agar mampu mengembangkan hingga pada titik yang diimpikan yaitu kehidupan bahagia dan komplit.

Menurut Al-Rasyidin (2009: 99), arti dari tarbiyyah, ta'lim dan ta'dib, Pendidikan Islami itu sendiri bisa diartikan serupa sistem dari bagian pembentukan lingkungan yang sehat bagi individu sebagai peserta didik untuk menggali potensi yang ada pada dirinya seperti, aljism, al-'aql, al-nafs dan al-qalb agar mampu mewujudkan syahadah primordialnya terhadap wujud dan ke Maha Agungan Allah S.W.T., melalui penerapan peran dan fungsi penciptaan individu itu sendiri yaitu sebagai makhluk Allah S.W.T. dan Khalifah Allah.

Dari pengertian di atas disimpulkan, bahwa pada intinya pendidikan itu sendiri berusaha mendorong proses edukasi rohani dan jasmani individu atau sekelompok seseorang untuk menerapkan kodrat individu yang berpanutan pada prinsip ajaran Islam agar terciptanya individu yang mempunyai budi yang luhur akhlak yang terpuji, serta patuh dan taat pada Allah S.W.T. dengan menerapkan apa yang diperintahkan dan menjauhi laranganNya agar mendapatkan suatu kebahagiaan yang layak baik di dunia ini maupun di hari akhir kelak. Di dalam ajaran agama Islam menyandang dua pegangan hidup yaitu Al-Qur'an dan sunnah nabi 
Muhammad S.A.W. yang berperan sebagai pegangan hidup dalam memutuskan segala perintah dalam kehidupan dan pegangan itu menjadi karakter esensi Islam. Panadangan dan keyakinan dilandaskan pada wahyu yang disampaikan oleh Allah Azza wa Jalla melalui perantara malaikat Jibril terhadap nabi Muhammad S.A.W. yang bersifat mutlak.

Menurut Ulil Amri (2012: 1), pada saat ini, pendidikan Islam menghadapi darurat nilai-nilai Islam yang dapat membawa kemerosotan. Para peneliti pendidikan sudah menganalisa bebarapa penyebab dari terjadinya kemerosotan tersebut, salah satunya yaitu materi kehidupan yang tidak sesuai dengan pedoman sumber aslinya, hilangnya uswah hasanah dan akidah yang murni dan penerapan nilai-nilai Islami. Untuk memecahkan masalah tersebut harus merujuk pada sumber utamanya yaitu AlQur'an, salah satu surah yang dapat dijadikan jawaban dari beragam masalah tersebut ialah surah Al-Hadid.

Sejak masa nabi Muhammad S.A.W. nama Al-Hadid telah mahsyur dikalangan mereka. menurut Hikmat Basyir (2016: 772), Penamaan Al-Hadid itu sendiri diadopsi dari kata itu sendiri yang terkandung pada surah Al-Hadid ayat 25. Dalam surah Al-Kahf memang juga terdapat kata al-hadid pada ayat 96 namun kisah ashabul kahfi lebih menarik pada surah itu maka dinamakan al-kahfi dan disini disebut al-hadid.

Adapun tema utama dari Al-Hadid adalah mengingatkan kebesaran dan kuasa Allah juga mengingatkan pentingnya perintah berinfak di jalan Allah S.W.T. serta menjauhi kekerasan hati yang merupakan sifat dari orang Yahudi. Dalam hal ini thabâthaba'i beroerintasi pada perintah berinfak, adapun pendapat Sayyid Quthub bahwa tema dalam surah ini berorientasi pada pencapaian dalam dalam kepribadian hakikat keimanan sehingga seluruh totalitas pada diri manusia sampai kepada Allah S.W.T., tidak pelit dan bakhil dalam menafkahkan harta dijalan Allah. Pada hakikat tersebut itulah yang membuat pribadi seseorang menjadi rabbâni, dasarnya ialah tolok Ilahi dan nilai-nilai yang diperjuangkan dan bersegera menggapainya.

Surah Al-Hadid merupakan surah yang ke 95 dari segi urutan turunnya, apabila dinyatakan surah ini Madaniyyah. Beberapa ulama mengungkapkan bahwa Al-Hadid turun sesudah Az-Zilzalah dan sebelum surah Al-Qital, menurut cara perhitungan ulama Mekkah, Madinah dan Syam jumlah ayat pada surah ini terdapat 28 ayat, akan tetapi menurut ulama Kufah dan Basrah ayat pada surah ini terdapat 29 
ayat. Sebagaimana yang telah dipaparkan sebelumnya bahwa semua ayat pada AlQur'an memiliki mukjizat tersendiri sehingga dapat dipahami maknanya seluasluasnya. Dalam memahami dan menggali ayat dalam Al-Qur'an telah benyak menghasilkan tafsir-tafsir yang ditulis oleh ulama dari berbagai belahan dunia, baik ulama salaf maupun khalaf. Dalam hal ini menggambarkan bahwa dalam menafsirkan ayat Al-Qur'an menghasilkan pemahaman yang luas yang dapat diambil hikmah dan pelajaran agar dapat menjadi panduan dalam kehidupan, teladan dan diinternalisasikan sebagai i'tibar dari pendidikan Islam sehingga dapat menghasilkan insan yang memiliki etika dan moral, memiliki jasmani dan jiwa yang sehat serta mengerjakan perintah Allah dan menjauhi larangan-Nya.

Kemudian Allah menjelaskan tujuan diutusnya para rasul, yaitu mengatur urusan-urusan kehidupan, Allah menjelaskan, "Sungguhnya Allah S.W.T. mengutus para rasul-Nya dengan membawa kebenaran nyata" Yakni, demi Allah S.W.T. mengutus makhluknya yaitu para malaikat kepada para Nabi dan RasulNya dengan membawa wahyu, dan kami utus para Nabi dengan membawa mukjizat yang nyata dengan bukti-bukti yang jelas, Allah S.W.T. juga menurunkan Kitab kepada mereka yakni Kitab sebagai nama jenis tercakup di dalamnya semua kitab Samawi seperti, kitab Taurat, Jabur, Injil dan Al-Qur'an. Kami juga menurunkan neraca (keadilan) bersama mereka, yakni keadilan dalam hukum, artinya Kami memerintahkan keadilan itu kepada mereka, agar umat manusia mengikuti kebenaran dan keadilan yang mereka perintahkan, agar kehidupan mereka berdiri di atas keadilan itu, sehingga mereka berinteraksi satu sama lain secara objektif dalam semua perkara mereka, baik perkara agama maupun perkara duniawi.

Kami menciptakan besi dan barang tambang lain, Kami menjadikannya sebagai penghalang terhadap orang yang tidak menerima suatu kebenaran dan bahkan membantahnya setelah disampaikannya hujah, sebab di dalam besi tersebut terdapat kekuatan penghalang. Di dalamnya juga terdapat banyak manfaat bagi umat manusia, mereka memanfaatkannya untuk berbagai kebutuhan dan sendi kehidupan mereka, seperti peralatan makan, kerangka rumah, pembuatan tangga, kehidupan ekonomi, penciptaan perdamaian ataupun peperangan dan lain sebagainya. Ada kata yang tersamarkan setelah Allah mengatakan sangat banyak kegunaanya untuk manusia. Penjabarannya: dan ada 
banyak manfaat bagi manusia agar manusia memanfaatkannya. Kata yang tersembunyi sebagai pengantar untuk kalimat yang diungkapkan dengan jelas sesudahnya, yaitu, supaya Allah S.W.T. siapa kelak yang menolong dan berjihad pada agama-Nya.

Sesungguhnya Allah menetapkan semua adalah untuk mendapati, siapa saja bagi hamba Allah S.W.T. yang akan membela agamaNya dan juga para utusanNya dan mampu menolak permusuhan orang-orang dzalim dan menolong rasulrasulnya beserta kaum mukminin tanpa bantuan mereka.

Menurut Wahbah Zuhaili (2013: 598), membentuk sebuah negara yang kuat dan terhormat dengan segala nilai sistem, aktivitas dan kekuatan warganya, serta kemandirian dalam hal jihad, pengorbanan, industri, pertanian dan perdagangan, itulah yang dikehendaki Allah dari diturunkannya syariat-syariat dan diutusnya rasul-rasul. Di dalamnya terdapat kebaikan, kemuliaan, keterlindungan dan penjagaan terhadap kehormatan dan hak-hak.

Muftie menyatakan (2004: 45), bahwa para mufassirin klasik tidak menafsirkan kata waanzalnal hadiida sebagai 'Kami telah menurunkan besi' sebagaimana terjemahannya 'Kami telah turunkan kepada mereka al-kitab dan juga al-mizan yaitu berupa keadilan, keseimbangan, kesamarataan, keselarasan dan kesepadanan. Kata yang tersembunyi menjadi pengantar untuk kalimat yang diungkapkan dengan jelas sesudahnya, yaitu, dan supaya Allah S.W.T. mendapati siapa saja dari hambaNya yang membela dan berjihad pada agama-Nya Untuk menunjukkan bahwa kata tersembunyi inilah yang dimaksud. dengan analisa karena belum ditemukan bahkan belum terbayangkan oleh para mufassirin klasik bagaimana langit menurunkan besi. Kata yang tersembunyi inilah yang akan menjadi sebuah pengantar untuk kalimat yang diungkapkan dengan jelas sesudahnya, yaitu dan supaya Allah S.W.T. mendapati siapa saja dari hambaNya yang membela agama-Nya. Untuk menunjukkan bahwa kata tersembunyi inilah yang dimaksud.

Allah S.W.T. menurunkan besi, dimana besi memiliki sifat yang sangat kuat, yaitu salah satunya. kekuatannya dalam berperang dan berdamai, juga mengandung "berbagai manfaat bagi manusia". Kemajuan dunia pada saat ini bertopang pada besi" dan agar Allah S.W.T. mendapati siapa saja dari hambaNya yang akan membela agama-Nya dan juga para utusan-Nya, padahal mereka tidak melihat Allah". Bagian ini 
menerangkan jihad dengan senjata. Sebuah penyampaian yang sepadan dengan konteks surah yang tengah membahas pengabdian dengan jiwa dan harta. Setelah membicarakan orang-orang yang menolong Allah S.W.T. dan juga para utusan-Nya, padahal mereka sama sekali tidak melihat-Nya, surah ini dilanjutkan dengan penjelasan makna menolong Allah S.W.T. dan juga utusan-Nya, yaitu menolong manhaj dan dakwah-Nya, sebab Allah Ta'ala tidak memerlukan pertolongan.

Menurut Wahbah Az-Zuhaili (2013: 598), Sesungguhnya Allah menetapkan semua ini adalah untuk mengetahui, pengetahuan sebagai kesaksian dan wujud keberadaan, siapa saja dari hamba-Nya yang akan membela agama-Nya dan para utusan-Nya dengan ikhlas, dengan menggunakan besi sebagai senjata untuk berjihad dan melawan musuh. Sesungguhnya Allah Maha kuat dan Maha kuasa, Maha perkasa dan Maha menundukkan, mampu menolak permusuhan orang-orang zhalim dan menolong rasul-rasul-Nya beserta kaum muslimin tanpa membutuhkan (bantuan mereka).

Menurut Muftie (2004: 45), membentuk sebuah negara yang kuat dan terhormat dengan segala nilai, sistem, aktivitas dan kekuatan warganya, serta kemandirian dalam hal jihad, pengorbanan, industri, pertanian dan perdagangan, itulah yang dikehndaki Allah dari turunkannya syariat-syariat dan diutuskannya rasulrasul. Di dalamnya terdapat kebaikan, kemuliaan, keterlindungan dan penjagaan terhadap kehormatan dan hak-hak. Ketiga, nilai Fungsional. Kata yang tersamarkan setelah firman Allah: wa manaafi'u linnaasi (dan banyak manfaat bagi manusia), penjabarannya: dan ada banyak manfaat bagi manusia agar manusia memanfaatkannya.

Allah S.W.T. menjelaskan pada ayat wa manaafi'u linnaasi (dan sangat banyak manfaat bagi manusia): Menurut Muftie (2004: 56), ayat ini menginspirasi manusia akan salah satu sifat besi, yakni amat tajam, sehingga oleh manusia, besi banyak digunakan untuk dalam kesibukan seharihari, seperti bakal membentuk mata bajak, kampak, parang, gergaji dan alat-alat tenun, berladang (seperti cangkul dan sabit), memasak (seperti pisau), memproduksi roti dan segala hal yang manusia tidak akan bisa menjalani aktifitas kecuali dengan memanfaatkan alat tersebut.

Pokok persoalan yang timbul pada penelitian ini berupa hal yang paling menarik dari penamaan surah Al-Hadid ini 
memuat beberapa pokok tema besar, di antaranya sebagai berikut:

1. Beribadah kepada Allah S.W.T. dan bertasbih (menyucikan-Nya) di setiap waktu

2. Perintah untuk beriman dan berinfak

3. Kondisi kaum munafik di akhirat

4. Anjuran untuk takut kepada Allah S.W.T. dan sedekah

5. Kondisi dunia dan hakikat akhirat

6. Musibah, takdir dan sistem hidup

7. Kesatuan prinsip-prinsip syariat.

Berlandaskan dari latar belakang tersebut, maka peneliti tertarik untuk melakukan penelitian dengan judul "NilaiNilai Pendidikan Dalam Surah AlHadid". Dengan tujuan penelitian ini dapat menyampaikan informasi bagi para pendidik dan peserta didik atau pelajaran bagi masyarakat saat ini untuk menata kepada proses pembelajaran ke arah yang lebih baik, bukan hanya cerdas secara emosional namun juga mampu cerdas secara spiritual.

\section{B. METODE PENELITIAN}

Penelitian ini menggunakan studi pustaka (library research method). Peneltian kepustakaan ( library research method) merupakan salah satu studi yang menggunakan dokumen dengan arti segala sumber data bermula dari subjek kajian yang tercantum pada materi pengkajiannya, berhubungan dan berkaitan dengan nilai-nilai pendidikan. Singkatnya, model penelitian ini, untuk mendapatkan data penelitian menjadikan perpustakaan sebagai sumber data.

Dalam pandangan Mestika Zeid, salah satu jenis penelitian library research method (penelitian yang berorientasi kepustakaan) merupakan sebuah penenlitian yang memperoleh data penelitiannya dengan memanfaatkan sumber perpustakaan. Sepadan dengan namanya, yaitu kajian pustaka menggambarkan salah satu dari bentuk kajian yang menjadikan bahan yang sifatnya tercantum menjadi bahan dari penelitiannya. Hal ini juga senada dari pendapat Subagyo bahwa kajian pustaka itu sendiri menggambarkan salah satu pengkajian yang datanya diinventarisir, digali, diolah dari berbagai sumber kajian tecantum: berupa surat khabar, buku, risalah dan sebagainya. Maka adapun langkah untuk mendapatkan inti dari informasi kajian tertulis tersebut dengan memahamai, membaca dan menelaah bacaan kitab tafsir dan asal-muasal kajian lainnya berhubungan dengan permasalahan yang dikaji. 
Menurut Masri Singarimbun dan Sofian Effendi (1989: 70), Library Research Method (Penelitian kepustakaan) merupakan sebuah penelaahan yang digunakan dengan cara melakukan studi terhadap sumber kajian tertulis yang berhubungan dan berhubungan pada letak inti permasalahan yang dikaji dengan deskripsi. Sebuah analisis yang membentuk subjek pustakanya sebagai sumber data utamanya yang ditujukan untuk menghasilkan konsepsi yang sudah didapatkan oleh para pakar dan ahli sebelumnya, mengikuti perkembanganperkembangan dari sebuah penelitian di bagian yang akan dikaji, mendapatkan orientasi yang mengenai topik yang dipilih serta menggunakan seluruh data sekunder dan menolak adanya duplikat penelitian.

Adapun penelitian yang akan dibahas dalam tesis ini menyangkut sebuah konsep pendidikan dalan Alquran, pendekatanpendekatan yang akan dipakai ialah pendekatan ilmu pendidikan dan juga ilmu tafsir melalui ayat-ayat Al-Qur'an. Penelitiann ini bertitik fokus pada surah Al-Hadid di dalam Al-Qur'an, karena titik fokus pada penelitian ini adalah Al-Qur'an, maka proses-proses pendekatannya juga dengan salah satu model tafsir.

Metode yang cocok dalam penelitian ini ialah metode yang menggunakan metode tahlili yang juga didukung metode maudhu'i dalam merumuskan ayat-ayat alquran yang berkaitan dan berhubungan dengan pokok dari kandungan surah AlHadid dalam Al-Qur'an. Adapun alasan penulis menggunakan metode tahlili dengan didukung metode maudhu'i dalam mengkaji nilai-nilai pendidikan dalam surah Al-Hadid terdapat kesesuaian dalam penelitian, sebab penelitian ini mengkaji nilai-nilai dalam surah tertentu, maka metode tahlili berfungsi untuk menganalisis surah Al-Hadid dan metode maudhu' $i$ untuk mengelompokkan tema dari pembahasan yaitu nilai-nilai pendidikan sehingga permasalahan penelitiaan yang diinginkan akan dapat menghasilkan sesuatu yang komprehensif.

Sedangakan untuk sumber data, pada hakikatnya didalam pengkajian ini, penulis menarik sebuah sumber data dari kitabkitab tafsir Al-Qur'an dan kajian tertulis yang dalam hal ini memiliki relevansi dengan permasalahan yang diteliti oleh peneliti. Adapun data yang akan diperoleh terdiri dari dua jenis, yaitu:

1. Data Primer

Sumber dari data primer untuk mengkaji penelitian ini adalah tafsir Al-Misbah karangan Quraish Shihab, tafsir Al-Wasith karangan Wahbah Az-Zhuhaili 
dan tafsir Muyassar karangan Hikmat Basyir.

2. Data Sekunder

Sumber data sekunder yang dipakai untuk mengkaji penelitian ini ialah tafsir Azhar karangan Hamka, tafsir Ibnu Katsir karangan Abu Fida bin Katsir Addamsyq, tafsir Jalalain karangan Jalaluddin As-Suyutu dan Jalaludin Al-Mahalli dan segala sesuatu yang terkait dengan permasalahan dalam penelitian ini, berupa jurnal, artikel, karya ilmiah yang relevan.

Adapun tehnik dalam pengumpulan data yang dipakai dalam pengkajian ini ialah:

1. Memeriksa ayat-ayat dan haditshadits yang berkaitan dengan masalah yang dikaji

2. Menyaring ayat-ayat dan haditshadits yang akan menjadi bahan primer dan sekunder yang sesuai dengan penelitian ini

3. Menambah referensi lain yang bertepatan dengan topik permasalahan yang dikaji berupa kitab-kitab, buku, jurnal dan lainnya yang selaras dengan kajian penelitian ini.
Dalam hal teknik analisis data, penelitian ini menggunakan verifikasi data yang bermaksud agar memperoleh informasi konkrik yang berhubungan dengan problem yang dikaji. Setelah keseluruhan dari data terhimpun, maka tahap setelahnya adalah memberikan analisa terhadap isi teks. Data yang didapatkan dari sumbernya, baik dari data inti yaitu primer maupun data dukungan atau sekunder, setelah itu akan dianalisis dengan mamakai teknik analisa terhadap isi (content analysis).

Pandangan Noeng Muhadjir: Pemakaian teknik analisa terhadap isi, harus memiliki 3 tahap yang dilakukan peneliti, yaitu: 1) menentukan sebuah poin dan kata kunci yang akan dicari dalam dokumen yang akan di kaji dan diteliti, 2) memberikan makna atas tema dan kata kunci, 3) memberikan definisi internal.

Berlandaskan pemaparan diatas, adapun analisa terhadap data pada pengkajian ini menggunakan 3 alur tersebut yaitu: 1) Menetapkan tema dan juga kata kunci, disebabkan dalam surah Al-Hadid tidak disebutkan secara terang mengenai terminologi dari konsep pendidikan, akan tetapi hanya indikasiindikasi saja, maka dari itu peneliti tidak memilih sebuah kata kunci akan tetapi hanya sebuah tema yang bersifat umum 
saja yang berkaitan pada problem yang akan diteliti. Dalam konteks pengkajian ini adapun tema yang diarahkan adalah besifat konsep pendidikan yang dirangkum seperti nilai akidah, akhlak, syariat, sosial, jihad, iman, dan ibadah yang ditelusuri dan diidentifikasi dalam surah Al-Hadid. 2), memberikan interpretasi arti atas tema tersebut dengan langkah mengamati dan menelaah tafsiran terhadap kitab-kitab yang dipakai terhadap tema konsep pendidikan dengan tujuan menerangkan segala makna dan keterangan yang akan dibahas. Usaha pemberian terhadap arti tema tersebut didukung dengan membandingkan serta menelaah dengan buku-buku, jurnal, karya ilmiah dan sumber tulisan lainnya yang berhubungan dengan pendidikan Islam. 3) memberikan definisi internal, yaitu mengukur keutuhan dan kepastian informasi dalam bentuk konsep pendidikan dalam surah Al-Hadid yang dapat dikenali dengan informasi lainnya secara menyeluruh dalam buku dan asal data yang setara.

Menurut Sugiyono (2008: 274), dalam hal menjamin keabsahan dari sebuah data, pengkajian ini memakai beraneka macam pengecekan kredibilitas data atau keaslian data, hasil penelitian kualitatif diteliti dengan perpanjangan sebuah observasi, kegigihan yang tinggi, trianggulasi serta berdiskusi bersama majlis diskusi, analitik peristiwa negatif dan juga memberchek.

Pada tahap pemeriksaan keabsahan dari data peneliti, baiknya memakai teknik ketekunan yang mendalam dalam pengkajian, ketekunan yang mendalam yang dimaksud ialah menjalankan sebuah peninjauan dengan lebih bijak dan cermat serta berkelanjutan. Peneliti dengan gigih memfokuskan kajian penelitiannya pada rumusan masalah untuk memilih berbagai nilai-nilai pendidikan dengan gaya membandingkan data dan temuan-temuan pada penelitian dengan memakai tafsir ayat Al-Qur'an.

Untuk menaikkan ketekunan, peneliti harus banyak menelaah berabagai aspek referensi dari buku, jurnal atau dokumen yang terkait pada sebuah temuan yang dikaji, dengan banyaknya menelaah maka pengetahuan dan pengalaman peneliti akan emakin bertambah luas sehingga mudah untuk mengamati data yang ditemukan dan dapat diyakini.

\section{PEMBAHASAN}

Berdasarkan uraian analisis tersebut, maka peneliti memukan beberapa perkara yang berkaitan dengan pokok masalah penelitian, yaitu:

Temuan pertama, nilai-nilai pendidikan yang terkandung dalam surah 
Al-Hadid, terdapat 15 nilai-nilai pendidikan: 1. Anjuran bersedekah pada ayat 7 dan 10, M. Quraish Shihab (2002: 413) mengemukakan bahwa, pada ayat ini Allah S.W.T. menyampaikan imbalan terhadap hambaNya yang beriman dan percaya kepada para utusan-utusan-Nya, serta dengan sukarela memberikan sedekahnya dijalan Allah, baik harta maupun apa yang dimilikinya, yang Allah titipkan padanya selama hidupnya, maka Allah akan memberikannya pahala yang besar sebagai balasan terhadap apa yang dilakukannya. 2.) Perintah beriman kepada Allah S.W.T. pada ayat 8, M. Quraish Shihab (2002: 415), mengemukakan bahwa, ayat di atas mendorong mereka beriman dan menampakan "keheranan" atau kecaman atas ketidaksegeraan mereka menyambut perintah itu dengan menyatakan bahwa: Mengapa kamu tidak bersegera memperkenankan perintah itu dan mengapa, yakni apa alasan dan halangan, kamu tidak beriman kepada Allah, yakni memperbaharui dan memantapkan iman kamu dari saat ke saat, padahal Rasul, yakni Nabi Muhammad S.A.W., senantiasa dan dari saat ke saat menyeru kamu supaya kamu beriman, yakni memperbaharui dan memantapkan Iman kamu, kepada Tuhan pemelihara dan pencurah aneka rezeki kepada kamu dan sungguh Dia yang Mahakuasa itu benarbenar telah mengambil perjanjian yang telah kamu akui dan ikat dengan Allah, yakni bersedia mengesakan dan taat kepada-Nya, sehingga sungguh buruk jika kamu mengingkari perjanjian itu. Jika kamu adalah orang-orang mukmin sejati atau ingin menjadi orang-orang mukmin sejati, bersegeralah memenuhi segala konsekuensi keimanan, antara lain berinfak dijalan Allah S.W.T. 3.) Larangan Bersikap Sombong, pada ayat 23, menurut Wahbah Zuhaili (2013: 598), Kami memberitahukan hal ini kepada kalian supaya kalian tidak bersusah hati pada kenikmatan duniawi yang kalian pasti kalian tinggalkan, dan tidak bergembira atas kegembiraan disertai sikap sombong dan pongah atas apa yang akan datang. Maka, janganlah bersedih atas apa yang telah berlalu, sebab sekiranya sesuatu itu telah ditakdirkan niscaya akan terjadi, dan janganlah bersenang hati atas datang atau diberikan kepada kalian, sebab segalanya itu merupakan ketetapan Allah dan rezekiNya bagi kalian. Allah akan menghukum siapa saja yang bersikap sombong, membanggakan diri kepada orang lain, dan menonjolkan harta serta kehormatannya. 4.) Menegakkan Keadilan, pada ayat 25, M. Quraish Shihab (2002:446), mengemukakan bahwa, pada ayat ini Allah 
menggambarkan maksud dan tujuan Allah menurunkan rasul-rasul-Nya, kitab suci dan juga neraca tidak lain adalah agar kehidupan manusia menjadi baik, dalam suatu masyarakat yang adil. Begitu juga, Allah menurunkan besi dengan maksud menjadikannya sebagai penegak keadilan itu sendiri, yang selaras dengan infak untuk melaksanakan jihad di jalan Allah S.W.T. isi kandungan ayat ini juga dapat dipahami sebagai sebuah peringatan dan nasehat kepada setiap orang yang belum bersungguh-sungguh menjalankan perintah Allah S.W.T. yang sesuai dengan penciptaannya. Allah memberikan terhadap mereka harta, sudah sepatutnya mereka berinfak, begitu juga Allah mengutus rasul-rasul-Nya hendaklah ditaati dan dihormati, dan Allah menciptakan besi untuk orang-orang yang senantiasa membangkang kepada Tuhannya. 5.) Anjuran Meminta Ampun, pada ayat 21, menurut Hikmat Basyir (2016: 754), Allah menyuruh kepada manusia agar bersegera memohon ampun kepada-Nya, untuk mendapatkan ampunan, dengan taubat yang sahih (taubat nasuha) dan senantiasa meninggalkan kemaksiatan yang pernah diperbuat, agar memperoleh ampunan Allah dan surga yang lebarnya meliputi langit dan bumi, yang dihadiahkan untuk siapa saja yang beriman kepada Allah, hal demikian merupakan keutamaan dari Allah S.W.T. Ia memberikan terhadap siapa saja yang Ia kehendaki. Surga didapatkan karena rahmat dan karunia-Nya. Allah adalah Maha Pengampun dan Pemberi rahmat bagi hamba-Nya yang beriman. 6.) Larangan Berperilaku Kikir/Pelit, pada ayat 24, menurut Hikmat Basyir (2016: 754), orang yang bersikap sombong lagi kikir dengan seluruh hartanya, dan berat hati memberikan hartanya di jalan Allah dan senantiasa menyuruh orang lain untuk melakukan hal demikian dengan menghiasinya untuk mereka, maka barang siapa yang lari dari ketaatan keapada Allah , maka sesungguhnya ia telah merugikan dirinya sendiri, ia tidak sama sekali merugikan Allah S.W.T. Allah Maha Kaya lagi Terpuji, yang memiliki seluruh sifat sempurna dan baik. 7.) Balasan Berupa Hukuman (Punishment) pada ayat 15, Sedangkan menurut Wahbah Zuhaili (2016: 591), wahai kaum munafik, pada hari ini tidak diterima dari kalian tebusan yang kalian bayarkan untuk membebaskan diri kalian dari api neraka atau adzab, juga tidak diterima dari orang-orang yang kafir kepada Allah secara zahir dan batin. Tempat tinggal yang akan kalian jadikan tempat perlindungan adalah neraka, ia lebih cocok untuk kalian dari tempat 
tinggal manapun. Itulah seburuk-buruk kesudahan yang akan kalian jalani yaitu neraka. 8.) Balasan berupa hadiah (Reward), pada ayat 11, Adapun menurut Hikmat Basyir (2016: 754), barang siapa yang dengan suka rela membagikan kekayaanya di jalan Allah dengan mengharapkan ridho Allah S.W.T. tanpa merasa beban dan menghitung-hitung apa yang sudah diberikan untuk Allah, maka Allah akan melipatgandakan pahala baginya sebagai balasan atas kebaikannya, baginya balasan yang setara, yaitu surga. 9.) Hakikat hidup di dunia, pada ayat 20 , Adapun menurut Hikmat Basyir (2016: 754), Ketahuilah oleh kamu sekalian, bahwa kehidupan sekarang adalah hanya sebuah kesenangan dan permainan belaka, jasmani bersenda gurau dan hati bermain, bermegah- megahan akan membuat senang dan bangga oleh pemiliknya, begitu juga berlomba dengan memperbanyak anak dan harta, Allah memberikan perumpamaan dalam ayat ini seperti hujan yang mejadikan tananam menggembirakan petani, kemudian berselang waktu tanaman itupun menjadi tua dan menjadi kering setelah itu gugur dan hancur. Pada hari alkhirat, Allah menyiapkan Azab yang sangat pedih kepada orang-orang yang ingkar pada Allah dan Allah memberkan ampunan-Nya kepada mukmin. Barang siapa yang menjadikan kehidupan dunia sebagai tujuan hidupnya dan melupakan kehidupan akhirat, maka hal itu hanyalah kesenangan yang memperdayanya. 10) Percaya kepada Qadha dan Qadar, pada ayat 22, Adapun menurut Hikmat Basyir (2016: 754), Setiap sesuatu yang ada di dunia ini dan juga yang menimpa pada diri manusia berupa kelaparan, takut, kekurangan makanan dan buah-buahan, penyakit dan seluruh musibah lainnya, hal itu semua sudah Allah tetapkan di Lauh Mahfudz, yang penciptaanya sebelum semua makhluk Allah diciptakan, dan hal demikian sangat mudah bagi Allah. 11.) Bertasbih Kepada Allah S.W.T. di Setiap Waktu, pada ayat 1, menurut Hikmat Basyir (2016: 747), bertasbih berarti menyucikan zat Allah S.W.T. karena Allah adalah zat yang Maha Sempurna dan jauh dari kekurangan seperti makhluk-Nya, maka sudah sepantasnya seluruh makhluk Allah baik yang di bumi maupun yang di langit menyucikan zat Allah yang mengatur seluruh tatanan kehidupan. 12.) Anjuran Berzikir (Mengingat) Allah S.W.T., pada ayat 17 , Menurut Hikmat Basyir, Allah S.W.T. dengan kekuasanNya mampu dengan mudah untuk mengatur segalanya, termasuk menghidupkan bumi dengan air hujanNya, setelah bumi itu mati (kering), 
kemudian setelah itu bumipun subur dan mengeluarkan tanaman-tanamannya, begitu juga Allah sangat mudah untuk menghidupkan hambanya setelah kematiannya pada hari kiamat kelak. Allah Maha Kuasa untuk melembutkan hati seseorang setelah sebelumnya hati itu keras. Sesungguhnya Allah telah menjelaskan kepada manusia bukti-bukti kekuasaan Allah S.W.T., maka hendaklah selalu berzikir, mengingat akan kuasa Allah dan mengambil pelajaran. 13.) Keutamaan Karunia Allah S.W.T., pada ayat 29, Menurut Hikmat Basyir, Allah S.W.T. memberikan kalian semuanya, agar para Ahli Kitab yang tidak sedikitpun meraih akan karunia dan rahmat Allah untuk diri mereka atau yang mereka bagikan terhadap orang lain, dan ketahuilah bahwasaanya anugrah dan rahmat hanyalah milik Allah dan Allah akan memberikannya kepada siapa saja yang Dia hendaki, karena Allah adalah zat yang Maha Baik kepada makhluk-Nya. 14.) Kitab Sebagai Petunjuk, pada ayat 26, Menurut M. Quraish Shihab, Allah S.W.T. mengutus para utusannya dan menurunkah kitab-Nya, yang pada ayat ini Allah S.W.T. menyebut dua orang rasul utama yaitu nabi Nuh dan Ibrahim. Dalam firman-Nya Allah S.W.T. bersumpah, bahwasannya Allah telah mengutus Nuh yang merupakan
Rasul Allah S.W.T. yang pertama dan juga merupakan ayah kedua manusia, sedangkan nabi Ibrahim ialah Bapaknya para nabi dan Rasul serta leluhur bagi bangsa Arab dan juga Israil, dan Allah jadikan pada keturunan keduanya kenabiaan, yaitu diangkatnya anak cucunya sebagai nabi dan rasul, dan Allah anugrahkan kitab suci pada mereka seperti Zabur dan juga Taurat, dan pada keturunannya kelaka ada yang mendapatkan petunjuk dari kitab suci tersebut dan banyak juga diantara mereka yang sesat dan fasiq. 15.) Larangan Munafik, pada ayat 13 dan 14, Adapun menurut Hikmat Basyir (2016:751) di akhirat orang yang munafik bagi dari lakilaki maupun yang perempuan, mereka mengatakan kepada orang-orang mukminun ketika mereka di ash-shirath, tunggulah kami, agar kami juga mendapatkan nur penerangan seperti kalian miliki, kemudian malaikat berkata kepada orang-orang yang munafik itu, mundurlah kalian ke belakang dan carilah sendiri cahaya kalian. Kemudian mereka dibedakan dengan batas, didalamnya terdapat kaum mukminun dan rahmat yang dilindungi sedangkan di luar ada kaum munafikun dan azab bagi mereka.

Temuan Kedua, Didalam Al-Qur'an terdapat pesan moral-moral yang sama 
sekali tidak bertentangan dengan prinsip kemanusiaan. Menurut Achyar Zein (2015: 9) hal ini disebabkan karna Allah S.W.T. yang menciptakan manusia dan seluruh ajaran-ajaran yang ada dalam Al-Qur'an juga bersumber dari asal yang serupa yaitu Allah S.W.T. maka dari itu Allah S.W.T. sangat mengetahui apa-apa saja yang berlaku pada kepentingan manusia itu sendiri. Isi kandungan surah Al-Hadid mempunyai nilai-nilai pendidikan Islam yang bisa diterapkan dalam kehidupan sehari-hari, seperti nilai anjuran bersedekah, perintah beriman kepada Allah S.W.T., larangan bersikap sombong, menegakkan keadilan, anjuran meminta ampun, larangan berperilaku kikir/pelit, anjuran berupa hukuman (Punishment), balasan berupa hadiah (Reward), hakikat hidup di dunia, percaya kepada qadha dan qadar, bertasbih kepada Allah S.W.T. di setiap waktu, anjuran berzikir (mengingat Allah S.W.T.), keutamaan karunia Allah S.W.T., kitab sebagai petunjuk, dan larangan munafik. Semuanya menggambarkan independensi sebuah pendidikan, keadilan, kerendahan hati, akidah, sikap, ibadah yang semua itu mempunyai kandungan pesan moral dan pembelajaran untuk diterapkan dalam kehidupan sehari-hari yang berlandaskan dari Al-Qur'an, terkhusus di era dewasa saat ini yang kerap berhubungan dengan kejahatan yang semakin kompleks. Menurut Achyar Zein (2015: 7), dalam dunia pendidikan Islam, faktor keimanan dan akhlak sangat urgen ditanamkan kepada peserta didik, misalnya mengajarkan sesungguhnya Allah S.W.T. Maha Mengetahui, Memperhitungkan dan Mendengarkan serta Maha Mengamati terhadap hamba-hamba-Nya, maka dari itu berbuatlah dengan baik dan benar sesuai hukum yang Allah syariatkan, dan Allah akan membalas terhadap apa saja yang kita perbuat.

Bukan hanya pada aspek akidah dan akhlak saja, tetapi dalam hal ini para penguasa di suatu daerah atau negara memiliki peran penting dalam mencegah sesuatu yang dapat merobohkan akidah dan akhlak yang benar. Menurut T.M. Hasbi Ash-Shiddieqy (1973: 72) Seorang penguasa yang merupakan seorang pemimpin hendaknya mampu akidah, ukhuwah dan akhlak yang ditanamkan di stiap institusi pendidikan. Maka diantara yang perlu bagi penguasa, baik dari aparatur negara, cendikiawan, pengusaha, filosofi memerangi ahli khurafat dan prasangka-prasangka yang tengah berkembang dalam masyarakat serta mengarahkan umat kepada akidah-akidah 
yang benar agar terwujud kesatuan dan kekuatan atas sendi kebenaran yang kuat.

\section{KESIMPULAN}

Setelah peneliti mendeskripsikan hasil penelitiannya tentang nilai-nilai pendidikan dalam surah Al-Hadid, maka dapat diambil kesimpulan sebagai berikut:

1. Adapun nilai-nilai pendidikan yang terkandung dalam Al-Qur'an pada surah Al-Hadid yang terdiri dari 29 ayat adalah sebagai berikut: 1) Anjuran bersedekah, 2) Perintah beriman kepada Allah S.W.T., 3) Larangan bersikap sombong, 4) Menegakkan keadilan, 5) Anjuran meminta ampun, 6) Larangan berperilaku kikir/pelit, 7) Anjuran berupa hukuman (Punishment), 8) Balasan berupa hadiah (Reward), 9) Hakikat hidup di dunia, 10) Percaya kepada qadha dan qadar, 11) Bertasbih kepada Allah S.W.T. di setiap waktu, 12) Anjuran berzikir (mengingat Allah S.W.T.), 13) Keutamaan karunia Allah S.W.T., 14) Kitab sebagai petunjuk, dan 15) Larangan munafik. Semuanya menggambarkan kemandirian pendidikan, keadilan, kerendahan hati, akidah, sikap, ibadah yang semua itu mempunyai kandungan pesan amanah, moral dan pembelajaran untuk diterapkan dalam kehidupan seharihari yang berlandaskan dari AlQur'an, khususnya di era dewasa saat ini yang kerap berhubungan dengan kejahatan yang semakin rumit.

2. Terdapat relevansi nilai-nilai dalam surah Al-Hadid terhadap pendidikan kontemporer, melihat kondisi pendidikan dan masyarakat saat ini, yang benar-benar dirundung krisis keimanan dan ketakwaan serta menurunnya akhlak dan moral yang pada akhirnya menciptakan pendidikan dan masyarakat itu sendiri sangat jauh dari kebenaran syariat Allah. Maka dari itu kajian ini mampu menjadi gambaran dan panduan dalam menata kembali yang lebih baik lagi pada era yang akan datang. Terlebih lagi bagi generasi muda Islam yang pada saat ini bimbang dan tidak memahami batasan yang jelas antara benar dan salah, baik dan buruk, terpuji dan tercela. Pendidikan Islam mengutamakan berartinya pendidikan tauhid sebagai dasar keimanan seseorang, pendidikan ibadah sebagai penegasan dari keimanan dan pendidikan akhlak sebagai hasil dari keimanan dan ibadah. Hal ini sangat penting untuk segera mungkin diterapkan pada setiap individu 
Muslim. Jika hal ini dapat diterapkan, maka akan melahirkan individu yang kontributif dan kolektif.

\section{DAFTAR PUSTAKA}

\section{Sumber dari Jurnal}

Saihu. (2019). Penanaman Nilai-nilai Pluralis Melalui Model Pendidikan Transfromatif Learning pada Pondok Pesantren Nurul Ikhlas Negara. Kordinat: Jurnal Komunikasi Antar Perguruan Tinggi, 18(1).

Saihu. (2019). Konsep Manusia dan Implementasinya dalam Perumusan Tujuan Pendidikan Islam Menurut Murtadha Muthahhari. ANDRAGOGI: Jurnal Pendidikan Islam, 1(2).

Saihu. (2019). Rintisan Peradaban Profetik Umat Manusia Melalui Peristiwa Turunnya Adam As Ke-Dunia. Mumtaz: Jurnal Studi Al-Quran dan Keislaman, 3(1).

Saihu. (2020). Etika Menuntut Ilmu Menurut Kitab Ta'lim Muta'alim. Al Amin: Jurnal Kajian Ilmu dan Budaya Islam, 3(1).

\section{Sumber dari Buku}

Agil Al-Munawar, S. (2005). Aktualisasi Nilai-Nilai Qur'ani. Ciputat: Ciputat Press.

Al-Zuhaili, W. (2013). At-Tafsir Al-Wasith Jilid 3. Jakarta: Gema Insani.

Khobir, A. (2007). Filsafat Pendidikan Islam: Landasan Teoritis dan Praktis. Pekalongan: STAIN Pekalongan Press.

Zein, M. (1987). Pendidikan Islam Tinjauan Filosofis. Yogyakarta: Tim Dosen Fakultas Tarbiyah IAIN Sunan Kalijaga.
N, Sudirman. (1992). Ilmu Pendidikan. Bandung: PT Remaja Rosdakarya.

Syah, Darwin. (2007). Perencanaan Sistem Pengajaran Pendidikan Agama Islam. Jakarta: Gaung Persada Press.

Al-Rasyidin. (2009). Percikan Pemikiran Pendidikan, dari Filsafat Hingga Praktik Pendidikan. Bandung: Cipta Pustaka Media Perintis.

Amri Syarif, U. (2012). Pendidikan Karakter Berbasis Al-Quran. Jakarta: Rajawali Pers.

Basyir, H., dk. (2016). Tafsir Muyassar: Memahami Al-Qur'an dengan Terjemahan dan Penafsiran Paling Mudah, Terj. M. Ashim dan Izzumi Karimi. Jakarta: Darul Haq.

Muftie A. (2004). Matematika Alam Semesta. Bandung: Dasur Basya'ir.

Jurnal Tafsir Fi Zhilalil Qur'an XI, Juz XXVII Adz-Dzariyat s.d. Al-Hadid.

J. Moleong, L.J. (2011). Metode Penelitian Kualitatif. Bandung: PT. Remaja Offset Rosdakarya.

Zed, Mestika. (2008). Metode Penelitian Kepustakaan. Yogyakarta: Buku Obor.

Subagyo, Joko. (1991). Metodologi Penelitian: Teori dan Praktik. Jakarta: Rhineka Cipta.

Singarimbun, Masri Singarimbun dkk. (1989). Metode Penelitian Survai, Jakarta: LP3ES.

Muhadjir, N. (1995). Metodologi Penelitian Kualitatif, Yogyakarta: Rake Sarasin.

Sugiyon. (2008). Metode Penelitian Kuantitatif dan Kualitatif, Bandung: Alfabeta.

Shihab, M.Q. (2002). Tafsir Al-Misbah, Pesan, Kesan dan Keserasian Alquran. Jakarta: Lentera Hati. 
Zein, A. (2015). Pesan-Pesan Moral dalam Aquran. Medan: Perdana Publishing.
Ash-Shiddieqy, T.M. Hasbi. (1973). Sejarah dan Pengantar Ilmu Tauhid. Jakarta: Bulan Bintang. 
